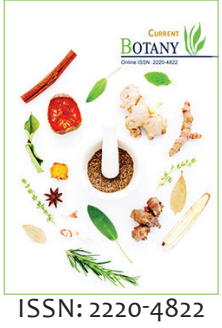

Received: April 06, 2020 Revised: August 11, 2020 Accepted: August 17, 2020 Published: August 28, 2020

\section{*Corresponding Author:} Ponnusamy Ponmurugan Email: ponmurugan@ buc.edu.in

\title{
Usnea dasaea, a further new addition to the Lichen Flora of Tamil Nadu State, India
}

\author{
Murugan Mariraj', Rajendran Kalidoss', \\ Kanivebagilu Shankaranarayana Vinayaka², Sanjeeva Nayaka³, and \\ Ponnusamy Ponmurugan ${ }^{1 *}$
}

\begin{abstract}
'Biomedical Research Laboratory, Department of Botany, Bharathiar University, Coimbatore-641 046, Tamil Nadu, India, 2Plant Biology Laboratory, Department of Botany, Sri Venkataramana Swamy College, Vidyagiri, Bantwal - 574 211, Karnataka, India, ${ }^{3}$ Lichenology Laboratory, National Botanical Research Institute, Lucknow - 226 001, Uttar Pradesh, India
\end{abstract}

\begin{abstract}
The present study addresses the addition of one new fruticose lichen species for the first time to the state of Tamil Nadu in Western Ghats, India. Usnea dasaea Stirt. is a new occurrence in Tamil Nadu. Descriptions of identification keys and distributions of such new species in south India provide useful information for identification. The new species addition of such lichen was identified and deposited at lichen herbaria, National Botanical Research Institute, Lucknow, Uttar Pradesh, India and Bharathiar University, Coimbatore, Tamil Nadu, India for further studies.
\end{abstract}

KEYWORDS: Usnea dasaea, new additions, Western Ghats, Tamil Nadu, fruticose lichen.

\section{INTRODUCTION}

The state of Tamil Nadu situated in the Southern part of India with a geographical area of $130,058 \mathrm{~km}^{2}$ is one of the lichen abundant area and parts of the hottest hotspots of Western Ghats Biodiversity [1]. It is located between latitudes $11.1271^{\circ}$ $\mathrm{N}$ and $78.6569^{\circ} \mathrm{E}$. Anaimudi, the highest peak of the Western Ghats, lies in the Tamil Nadu state with diverse vegetation with an altitude of about $2695 \mathrm{~m}$. The Western Ghats of Tamil Nadu state has rich lichen species (785 species) is confirmed by comparing them with other states such as Sikkim (634 species), Arunachal Pradesh (612 species), Assam (424 species), Manipur (374 species), Nagaland (334 species), Mizoram (182 species) and Tripura (30 species). The Kodaikanal hills, the part of Western Ghats in Tamil Nadu is one of the 40 protected areas established in 2008 and upgraded to "Palani hills Wildlife Sanctuary and National Park". Several researchers have explored lichen diversity in Kodaikanal hills in the past. However, a new addition has not been documented recently. Moreau and Moreau (1952) enumerated some taxa in Western Ghats [2]. Awasthi [3] described one new species Parmelia (Hypogymnia) pseudobitteriana from Kodaikanal hills. Awasthi [4] listed many species from Palani hills (Kodaikanal). Patwardhan and Kulkarni [5] described one new species Graphis asahinae and
Patwardhan and Makhija [6] discovered two species Lopadium ionexcipulum, and L. palniensis from Kodaikanal hills as new additions. Nayaka and Upreti [2] suggested that the Western Ghats might possess minimum of 200 new species and should be further surveyed. Sinha et al. [7] recorded a list of 411 new additions to India. Thus, totally 2714 lichen species are reported from India [7]. Previous literatures reported 785 species from the TN state [8]. By addition of one more species Usnea dasaea to the check list of Tamil Nadu lichens, now the number increases up to 786. Because, lichens are always exposed to the hazards of extinction by human exploitation activities all around, extensive exploration was carried out for documenting endangered species or economically important species of lichen additions in the selected area.

The genus Usnea is reported in many parts of the world. The thalli of this genus are described as fruticose form. The genus consists of more than 350 species. The lichen compound usnic acid is a secondary metabolite of the genus Usnea which is responsible for biological activities. Some species of Usnea are studied extensively while a few have to be explored. Formerly, in 2015, the Usnea dasaea Stirt was reported from Karnataka, the part of Western Ghats and is a new addition to Tamil Nadu [9]. Mesta et al. [10] reported several compounds such as tannin,

Copyright: $\odot$ The authors. This article is open access and licensed under the terms of the Creative Commons Attribution License (http://creativecommons.org/licenses/by/4.0/) which permits unrestricted, use, distribution and reproduction in any medium, or format for any purpose, even commercially provided the work is properly cited. Attribution - You must give appropriate credit, provide a link to the license, and indicate if changes were made. 
depsidone, and dibenzofurane from Usnea dasaea Stirt. This species is not cited in authenticated Awasthi's manual on "Compendium of Macrolichens from India" and therefore, it is mandatory to include Usnea dasaea Stirt in lichen flora database of India. An authentic new species addition reported in the present study was prepared with valid identification key, distinguishable characters and their current name.

\section{MATERIALS AND METHODS}

The study was based on lichen samples collected on field trips by the authors to Kodaikanal hills of Tamil Nadu, India (Figure 1). A survey of lichen population was carried out from October 2018 to December 2019 and concerned mainly with the distribution of lichen diversity and also noted that if any new lichens unspecified in the study area. The study assessed the collection of lichens and used taxonomic identification. The lichen specimen was investigated morphologically [11]. Chemical tests (K, C, $\mathrm{KC}$ and $\mathrm{PD}$ ) were employed to observe the colour reactions on lichen thallus. A majority collection of lichen specimens had been examined for cortical and medullary chemical compounds by thin layer chromatography method using solvent system C [12]. The morphological characters of lichen specimens were studied using Olympus SZ51 stereomicroscopes. The anatomical structures and soralia were observed with the Scanning Electron Microscope. The herbarium specimen was deposited in lichen herbaria, Bharathiar University, Coimbatore, Tamil Nadu, India and National Botanical Research Institute, Lucknow, Uttar Pradesh, India.

\section{TAXONOMIC DESCRIPTION}

\section{Usnea dasaea Stirt. Scott. Natur. 6:104(1881)}

Thallus was corticolous (Figure 2), erect, $3 \mathrm{~cm}$ long, yellowish - green, branches inflated, branches measured up to $2 \mathrm{~mm}$ in diam, tapering, curved at apices central axis solid, colorless, soralia, and isidiomorphs present on younger soralia but absent on mature ones, fibrils present, thallus showed soredia, isidia, pseudocyphellate and minute papillae.

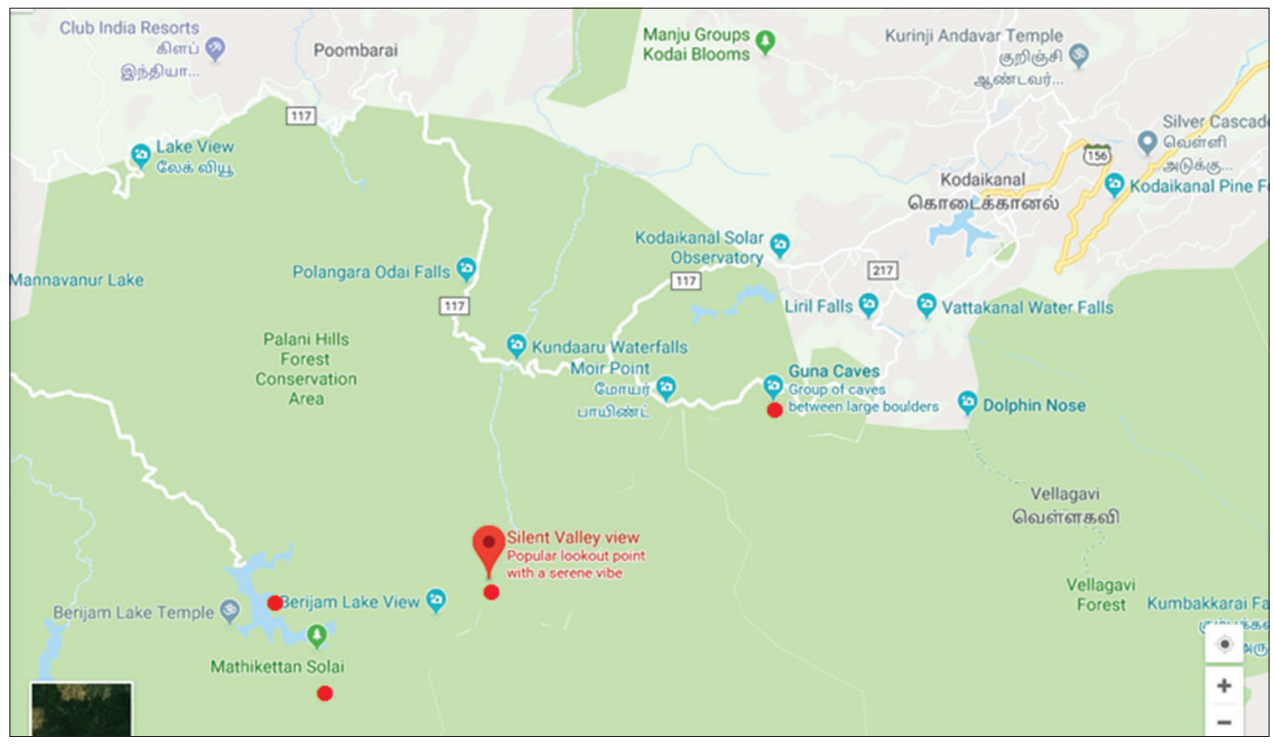

Figure 1: Kodaikanal hills location map, Tamil Nadu, India

Table 1: Comparison of Usnea species in terms of morphological, anatomical, biochemical and spot test results

\begin{tabular}{|c|c|c|c|c|c|c|}
\hline & Thallus & Soredia/Isidia & Pseudocyphellae/Papillae & Medulla & Chemistry & Compounds \\
\hline U.dasaea & $\begin{array}{l}\text { Erect - Sub-pendent } \\
\text { thallus, } 2-15 \mathrm{~cm} \text { long, } \\
\text { Inflated branches }\end{array}$ & $\begin{array}{l}\text { punctiform Soralia } \\
\text { Soreida present } \\
\text { Isidiomorphs } \\
\text { present }\end{array}$ & $\begin{array}{l}\text { Pseudocyphellae and } \\
\text { minute Papillae present }\end{array}$ & $\begin{array}{l}\text { central axsis } \\
\text { solid, colorless }\end{array}$ & $\begin{array}{l}\text { Medulla } \\
\mathrm{C}_{-}, \mathrm{K}-, \mathrm{KC}-, \mathrm{PD}+\end{array}$ & $\begin{array}{l}\text { Usnic acid } \\
\text { Psoromic acid } \\
\text { Norstictic acid }\end{array}$ \\
\hline U.glabrata & $\begin{array}{l}\text { Erect - Shrubby, } \\
2-5 \mathrm{~cm} \text { long, } \\
\text { Annular cracked } \\
\text { Inflated branches }\end{array}$ & $\begin{array}{l}\text { Concave Soralia, } \\
\text { Soredia granular, } \\
\text { Isidia Absent }\end{array}$ & $\begin{array}{l}\text { Pseudocyphellae and } \\
\text { Papillae Absent }\end{array}$ & $\begin{array}{l}\text { thick, very } \\
\text { loose, No } \\
\text { pigments }\end{array}$ & $\begin{array}{l}\text { Medulla } \\
\text { C-, K-,KC-,PD + }\end{array}$ & $\begin{array}{l}\text { Usnic acid } \\
\text { Salazinic acid } \\
\text { Norstictic acid } \\
\text { Protocetraric acid }\end{array}$ \\
\hline U.cornuta & $\begin{array}{l}\text { Erect - Shrubby, } \\
2-5 \mathrm{~cm} \text { long, } \\
\text { Inflated branches }\end{array}$ & $\begin{array}{l}\text { Soredia and Isidia } \\
\text { Absent }\end{array}$ & $\begin{array}{l}\text { Papillae present, } \\
\text { Pseudocyphellae } \\
\text { absent }\end{array}$ & $\begin{array}{l}\text { central axsis } \\
\text { solid, }\end{array}$ & $\begin{array}{l}\text { Medulla } \\
\mathrm{C}-,_{-} \mathrm{K}+, \mathrm{KC}-, \mathrm{PD}+\end{array}$ & $\begin{array}{l}\text { Salazinic acid } \\
\text { Norstictic acid } \\
\text { Protocetraric acid }\end{array}$ \\
\hline U.fragilescens & $\begin{array}{l}\text { Erect, Sub-pendent } \\
\text { thallus, } 3-8 \mathrm{~cm} \text { long } \\
\text { Inflated branches }\end{array}$ & $\begin{array}{l}\text { Rounded soralia, } \\
\text { Granular soredia } \\
\text { Isidia absent }\end{array}$ & $\begin{array}{l}\text { Pseudocyphellae } \\
\text { Absent, papillae present }\end{array}$ & $\begin{array}{l}\text { Thick, } \\
\text { central axsis } \\
\text { solid, }\end{array}$ & $\begin{array}{l}\text { Medulla } \\
\mathrm{C}-,_{-} \mathrm{K}+, \mathrm{KC}-, \mathrm{PD}+\end{array}$ & $\begin{array}{l}\text { Usnic acid } \\
\text { barbatic acid } \\
4-0 \text {-demethyl } \\
\text { barbatic acid } \\
\text { Protocetraric acid }\end{array}$ \\
\hline
\end{tabular}




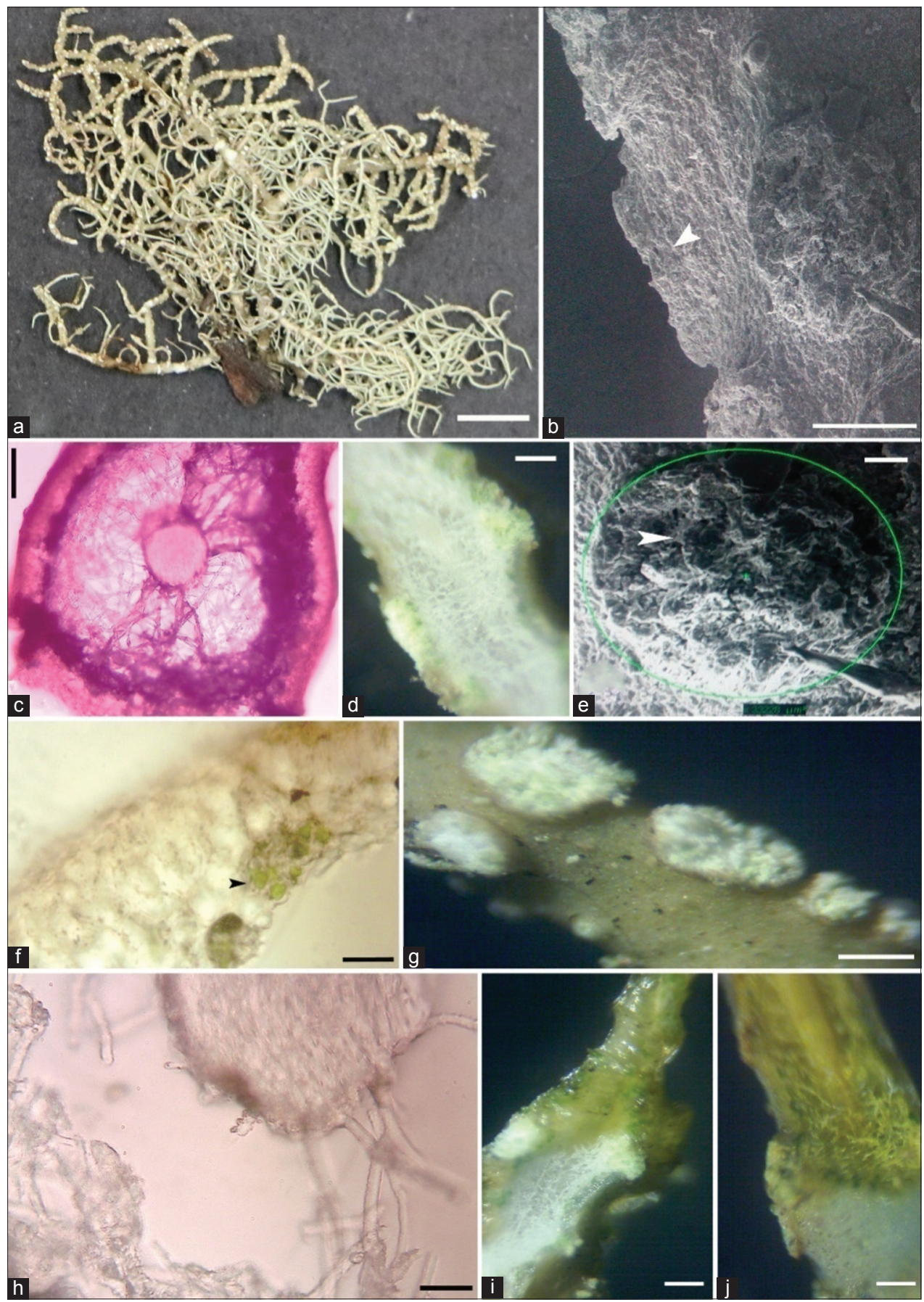

Figure 2: Usnea dasaea (a)Thallus, (b) SEM Image of soralia, (c) C.S. of thallus, (d) T.S of thallus, (e) SEM Image of soredia, (f) Algal cells of Trebouxia, (g) Punctiform of soredia, (h) Magnified structure of central stalk, (i-j) Spot test result of K-ive and PD+ive. (Scale bar A-5mm; B-200 4 m; C-50 $\mu \mathrm{m} ; \mathrm{E}-20 \mu \mathrm{m} ; \mathrm{G}-30 \mu \mathrm{m} ; \mathrm{F} \& \mathrm{H}-5 \mu \mathrm{m} ; \mathrm{D}, \mathrm{I}, \mathrm{J}-25 \mu \mathrm{m})$

Chemistry: The spot test reactions of cortex showed K-, C-, KC-, PD+ golden yellow. TLC test results showed the presence of psoromic acid, usnic acid and unidentified yellow spot (Figure 3).

Notes: U.dasaea is distinguished by erect thallus with tapering, curved apices, soralia elliptic longitudinally, isidiomorphs present on younger soralia but absent on mature ones, sorediate and isidiate both present on thallus.
Earlier the study conducted by Ohmura et al. [13] distinguished Usnea dasaea from U. cornuta, U. fragilescens, U. glabrata by the presence of soralia in detached fibrils (Table 1). However, it can be distinguished from other species by the presence of isidomorphs. Isidiomorphs are absent in other species.

Distribution: Earlier, the same species was reported from Taiwan at an altitude of $2400-2600 \mathrm{~m}$ above MSL and also recorded in European countries [14]. In India, the species is found in 


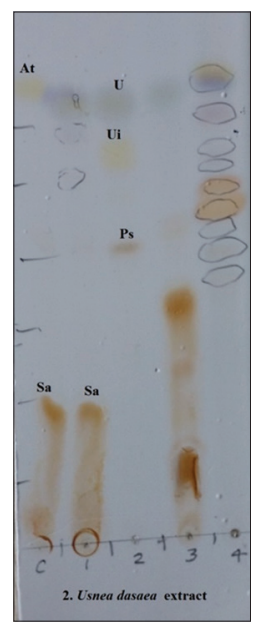

Figure 3: Compound identification of Usnea dasaea in thin layer chromatography solvent system A, (Ps) Psoromic acid (U) Usnic acid, (UI) Unidentified compounds, (U) Usnic acid, control (At) Atranorin (Sa) Salazinic acid

Kodaikanal hills of Tamil Nadu at an altitude of $2197 \mathrm{~m}$ above MSL. Usnea dasaea is new addition to Western Ghats of Tamil Nadu, India. [9,15-23].

\section{CONCLUSION}

Many new additions of lichens are being surveyed for their occurrence and biodiversity wealth of an ecosystem. One such lichen species, Usnea dasaea Stirt. belonging to fruticose form of lichen group is found to be occurred commonly from Pillar rocks in Kodaikanal hills, Tamil Nadu, the part of Western Ghats. Thus, the selected site is least explored for lichen wealth. In conclusion, $U$. dasaea has proved interesting chemical substances in medullary thallus. The supportive anatomical, morphological and chemical profiles in this present study would facilitate the lichenologists to further identify such species in many other parts of Western Ghats. It is suggested that the presence of lichen compounds such as tannins, dibenzofurane, psoromic acid and usnic acid can be subjected to further analyze and demonstrate their biological activities.

\section{ACKNOWLEDGEMENT}

The authors are indebted to Dr. D.K. Upreti, Director (Formerly), Lichenology Laboratory, CSIR-National Botanical Research Institute, Lucknow, Uttar Pradesh, India for allowing us to access the lichenology lab facilities. We acknowledge with thanks to Dr. A. Rajendran, Professor and Head, Department of Botany, Bharathiar University for his comments and suggestions. We are thankful to UGC SAP and DST FIST, Government of India for financial support to carry out this study.

\section{REFERENCES}

1. Rajkumar R, Shaijumon CS, Gopakumar B, Gopalakrishnan D. Extreme rainfall and drought events in Tamil Nadu, India. Climate Research. 2020;80:175-188.

2. Nayaka S, Upreti DK. Status of lichen diversity in Western Ghats, India. Sahyadri E-News, Western Ghats Biodiverstity Information System. 2005:

3. Awasthi DD. A new species of Parmelia from Kodaikanal, South India. Current Science. 1957;26:123-124.

4. Awasthi DD. Catalogue of the Lichens from India, Nepal, Pakistan, and Ceylon. Beihefte zur Nova Hedwigia, Heft 17. Verlag von J. Cramer, Weinheim; 1965.

5. Patwardhan P, Kulkarni C. Some new taxa of the family Graphidaceae from Western Ghats, southwestern India. Norwegian journal of botany. 1979;26:45-52.

6. Patwardhan PG, Makhija U. lichen genus Lopadium (Family lecideaceae) in the Western Ghats, southwestern India. Indian journal of botany. 1981;4:20-6.

7. Sinha GP, Nayaka S, Joseph S. Additions to the checklist of Indian lichens after 2010. Cryptogam biodiversity and assessment special. 2018;197:206.

8. Negi HR, Kareem A. Lichens: The unsung heroes. Amrut. 1996;1:3-6.

9. Mesta AR, Kanivebagilu SV, Rajeswari N. Distribution Pattern and Ecology of Usneoid lichens in Western Ghats, Southern India. Journal of New Biological Reports. 2015;4:247-254.

10. Mesta AR, Rajeswari N, Kanivebagilu VS. Distribution of bioactive compounds in Usneoid lichens from Western Ghats. Plant Archives. 2019;19:2163-2168.

11. Awasthi DD. compendium of the Macrolichens from India, Nepal and Sri Lanka. Bishen Singh Mahendra Pal Singh, Dehradun, India; 2007.

12. Orange A, James PW, White FJ. Microchemical methods for the identification of lichens. Twayne Publishers, USA.; 2001.

13. Ohmura Y. A synopsis of the lichen genus Usnea (Parmeliaceae, Ascomycota) in Taiwan. Memoirs of the National Museum of Nature and Science. 2012;48:91-137.

14. Randlane T, Torra T, Saag A, Saag L. Key to European Usnea species. Bibliotheca lichenologica. 2009;100:419-462.

15. Biju H, Bagool R, Nayaka S. Additions to the lichen flora of kerala state: Parmelioid macrolichens. Journal of Economic and Taxonomic Botany. 2010;34:890-7.

16. Abe R, Sekhar CR, Sasaki S, Shivananda K, Shinji M. Eastern Ghats' biodiversity reserves with unexplored lichen wealth. Current Science. 2013; 104:821-5.

17. Rashmi S, Rajkumar HG. Enumeration and new records of lichens in Kodagu district-a micro hotspot in Western Ghats of Karnataka, India. International Research Journal of Environmental Sciences. 2015;4:17-25.

18. Gupta N, Gupta V, Dwivedi SK. New addition to lichen flora of Uttar Pradesh, India. 2016;3:153-6.

19. Ponmurugan P, Ayyappadasan G, Verma RS, Nayaka S. Survey, distribution pattern and elemental composition of lichens in Yercaud hills of Eastern Ghats in southern India. Journal of Environmental Biology. 2016;37:407.

20. Logesh AR, Chinlampianga M, Shukla AC, Upreti DK. Studies on Lichens of Mizoram, Northeast India. Proceedings of the National Academy of Sciences, India Section B: Biological Sciences. 2017;87:445-457.

21. Rai H, Nayaka S, Upreti DK, Gupta RK. A New Record of Canomaculina (Parmeliaceae, Ascomycota) from Western Himalaya, India. Natl Acad Sci Lett. 2019;42:429-31.

22. Singh P. A new species of Cryptothecia (Arthoniales, Arthoniaceae) from the Western Ghats biodiversity hotspot, India. Phytotaxa. 2019;409:101-4

23. Guzow-Krzemińska B, Flakus A, Kosecka M, Jabłońska A, RodriguezFlakus P, Kukwa M. New species and records of lichens from Bolivia. Phytotaxa. 2019;397:257-79. 